\title{
25 Research Square \\ Consequences of Long-term Exposure to Increased Salinity on the Amphibian Skin Bacterium Erwinia Toletana
}

Antonieta Gabriel ( $\square$ antonietagc@ua.pt )

University of Aveiro: Universidade de Aveiro https://orcid.org/0000-0002-5928-5878

\section{Sara Costa}

University of Aveiro: Universidade de Aveiro

Isabel Henriques

University of Aveiro: Universidade de Aveiro

Isabel Lopes

University of Aveiro: Universidade de Aveiro

\section{Research Article}

Keywords: Erwinia toletana, Bioaugmentation, Salinization, Sea Level Rise, Tolerance, Long-ter exposure

Posted Date: February 13th, 2021

DOI: https://doi.org/10.21203/rs.3.rs-227580/v1

License: (c) (i) This work is licensed under a Creative Commons Attribution 4.0 International License.

Read Full License

Version of Record: A version of this preprint was published at Archives of Environmental Contamination and Toxicology on April 20th, 2021. See the published version at https://doi.org/10.1007/s00244-02100845-z. 


\section{Abstract}

Amphibian's skin bacterial community may help them to cope with several types of environmental perturbations, including osmotic stress caused by increased salinity. This work aimed at assessing if an amphibian skin bacterium could increase its tolerance to $\mathrm{NaCl}$ after a long-term exposure to this salt. $\mathrm{A}$ strain of Erwinia toletana, isolated from the skin of Pelophylax perezi, was exposed to two salinity scenarios (of $18 \mathrm{~g} / \mathrm{L}$ of $\mathrm{NaCl}$ ): (i) long-term exposure (for 46 days; $\mathrm{Et}-\mathrm{NaCl}$ ) and (ii) long-term exposure followed by a recovery period, (exposure for 30 days to $\mathrm{NaCl}$ and then to LB medium for 16 days; Et-R). After exposure, the sensitivity of $E$. toletana clonal populations to $\mathrm{NaCl}$ was assessed by testing $6 \mathrm{NaCl}$ concentrations (LB medium spiked with $\mathrm{NaCl}$ ) plus a control (LB medium). Genotypic alterations were assessed by PCR-based molecular typing method (BOX-PCR). Results shown that tolerance of E. toletana to $\mathrm{NaCl}$ slightly increased after the long-term exposure, $\mathrm{EC}_{50}$ for growth were: $22.5 \mathrm{~g} / \mathrm{L}$ (8.64-36.4) for EtLB; 30.3g/L (23.2-37.4) for Et-NaCl, and 26.1 g/L (19.3-32.9) for Et-R. Differences in metabolic activity were observed between Et-LB and Et-R and Et-NaCl and Et-R suggesting the use of different substrates by this bacterium when exposed to salinized environments. $\mathrm{NaCl}$-induced genotypic alterations were not detected. This work suggests that $E$. toletana exposed to low levels of salinity, activate different metabolic pathways to cope with osmotic stress. Which may be further explored to be used in bioaugmentation procedures in natural populations of amphibians exposed to salinization.

\section{Introduction}

Skin is one of the most important organs concerning amphibian's immune system, constituting a premier barrier to the surrounding environment (Colombo et al. 2015). It holds diverse components essential for amphibians' survival and fitness, namely: mucus glands, toxins and venom substances, antimicrobial peptides and a microbial community (i.e. the skin microbiome) that helps the organism to deal with pathogens and chemical contaminants (Kueneman et al. 2014; Colombo et al. 2015; Costa et al. 2016). This skin microbiome has been studied to better understand it's potential role in the amphibian tolerance to fungal infection (e.g. Batrachochytrium dendrobatidis) and it's use for probiotic bioaugmentation (Harris et al. 2009; Holden et al. 2015; Woodhams et al. 2016). In this context, bioaugmentation refers to the use of native (i.e. from the individual) and beneficial microorganisms (e.g. capable of producing protective metabolites and increased tolerance to a chemical), in order to improve the individual tolerance to external stressors (Harris et al. 2009; Bletz et al. 2013; Woodhams et al. 2016). In the case of amphibians, skin bacteria that are tolerant to environmental stressors (e.g. agrochemicals, chemical pollutants, salt and metal contamination, among others) could be augmented to improve the tolerance of amphibians to those stressors (Beebee and Griffiths 2005; Woodhams et al. 2016).

Amphibians are very sensitive to salinization, this stressor has been considered for a long time a global destabilizer of ecosystems equilibrium (e.g. Bernabò et al. 2013; Cañedo-Argüelles et al. 2013; Pereira et al., 2018; Estevéz et al., 2018). Salinity increase, or high concentrations of dissolved salts in ecosystems have been caused by different sources: natural causes (e.g. rainfall season), climatic changes (e.g. raise temperature causing evapotranspiration), anthropogenic activities (e.g. mining activity, use of de-icers) 
and sea level rise (e.g. causes seawater intrusion at coastal ecosystems) (Payen et al. 2016; Mulamba et al. 2019; Venâncio et al. 2020). Among these, the already occurring sea level rise emerged as a major cause for coastal ecosystems salinization. Many of these coastal ecosystems are considered hotspots of amphibian biodiversity, which anticipates a salinization risk for these amphibian communities. In fact, published work already reported that salinization may adversely affect amphibian's fitness (Kirwan \& Megonigal 2013; Santos et al., 2013; Mccoy 2017; Venâncio et al., 2019). As an example, Stănescu et al. (2017) reported that embryos of Pelobates fuscus and P. syriacus could not survive at salinities as low as $9 \%$. The microbiome in the skin of amphibians may play an important role in the capacity of tadpoles to tolerate salinized waters acting as a biological barrier for ions exchange, osmotic imbalance and regulation (Margesin and Schinner 2001).

Despite the fact that microorganisms may be affected by salinity fluctuations, many microbial communities are well-adapted to hyper salinity conditions, classified as halophiles (Margesin and Schinner 2001). Halophiles, are frequently used as a bioremediation tool and in bioaugmentation therapy to treat and prevent diseases (Geider et al. 2006; Miliute et al. 2015; Waditee-Sirisattha et al. 2016). Although, according to He et al. (2016) it is possible to acclimate microbes, such as bacteria to salinity stress conditions. For example, How et al. (2013) reported that Escherichia coli, a non-halophilic bacterium, was able to adapt to $11 \%(\mathrm{w} / \mathrm{v})$ of $\mathrm{NaCl}$ after being exposed for 80 passages to this compound. This capacity to acclimate or adapt to increased salinity constitutes an advantage to microbes, enabling their persistence in salt-contaminated environments. Native species are well adapted to their habitats, although, when an environmental change occurs, as for example an increase of salinity due to rise of sea level, it can be threatening to their survival (Payen et al. 2016). Since microorganisms can be very fast to adapt to environmental changes, they can be used as a tool to improve their hosts tolerance. The inherent microbiome of an amphibian host can be studied regarding their capacity to acclimate to environmental stress conditions (Harris et al. 2009). In consequence, bioaugmentation can be a practice to enhance hosts tolerance to environmental stressors with higher rate of success.

Considering the rational above, the present work aimed at assessing if an amphibian-skin bacterial isolate, could increase its tolerance to salinity after a long-term exposure. To attain this major goal exposure occurred under two salinity scenarios: long-term continuous exposure and long-term exposure followed by a recovery period. The bacterial isolate selected to conduct this work was Erwinia toletana, a bacterium present in the Pelophylax perezi'skin of reference sites (Costa et al. 2016) and agricultural fields (Miliute et al. 2015). Rojas et al. (2004b) and Silva et al. (2014) described Erwinia toletana as nonpathogen, Gram-negative, oxidase-negative and catalase-positive bacteria from Enterobacteriaceae family. Erwinia toletana is usually reported as being a co-existent bacterium with olive tree knot Pseudomonas savastanoi pv. savastanoi pathogen (Rojas et al. 2004). Scarce information is gathered about $E$. toletana tolerance to $\mathrm{NaCl}$ and bioaugmentation ability. However, some studies with other Erwinia species have been made to investigate and apply bioaugmentation in plants (Geider et al. 2006; Mills et al. 2006; Miliute et al. 2015). 


\section{Materials \& Methods}

\section{Bacterial strain}

The bacterium Erwinia toletana LB1-10 (GenBank Accession Number KT720377) was selected to carry out this study from a set of bacteria isolated from the skin of adults of Pelophylax perezi inhabiting a reference site, with no previous exposure to increased salinity (Costa et al., 2016).

Erwinia toletana, stored at $-80^{\circ} \mathrm{C}$ in NB-medium (Thermo Scientific, CM0003) with $15 \%$ glycerol, was recovered in sterilized solid LA medium and cultures were renewed three times to ensure no contamination and cells viability. A pre-inoculum of $E$. toletana was obtained by inoculating a colony in 5 $\mathrm{mL}$ of LB medium and incubating overnight at $28^{\circ} \mathrm{C}$ and $180 \mathrm{rpm}$. The inoculum to determine the growth curve was made with $500 \mu \mathrm{L}$ of the pre-inoculum in $50 \mathrm{~mL}$ of LB medium, incubated at the same conditions. Optical density, measured at $595 \mathrm{~nm}$, was followed constantly for one week.

\section{Long-term exposure and sensitivity assays}

To determine if long-term exposure of $E$. toletana to two salinity scenarios could cause an increase on its tolerance to $\mathrm{NaCl}$, clonal populations of $E$. toletana were exposed, for 46 days, to the following salinity scenarios: (i) long-term continuous exposure to the effective concentration of $\mathrm{NaCl}$ causing $10 \%$ of growth inhibition $\mathrm{EC}_{10}(\mathrm{Et}-\mathrm{NaCl})$ and (ii) long-term exposure (for 30 days) to the effective concentration of $\mathrm{NaCl}$ causing $10 \%$ of growth inhibition $\mathrm{EC}_{10}$ followed by the transfer of the clonal population to $\mathrm{LB}$ medium for the remaining 16 days (Et-R), to simulate a scenario where the aquatic system may recover after a long period of salinization (e.g. due to intense rainfall). Adding to these two scenarios, E. toletana was also exposed for a long-term (46 days) to LB medium (Et-LB), consisting in the control. The $\mathrm{EC}_{10}$ of $18 \mathrm{~g} / \mathrm{L}$ of $\mathrm{NaCl}$ was computed from a previous work (unpublished) where bacterial sensitivity to $\mathrm{NaCl}$ was tested through microdilution method. Five clonal populations of $E$. toletana were exposed per each of the three scenarios, i.e. Et-NaCl, Et-R and Et-LB. Exposure was carried out in 24-wells plates, with $2 \mathrm{~mL}$ of culture media (either LB or LB with $18 \mathrm{~g} / \mathrm{L}$ of $\mathrm{NaCl}$ ) in each well and inoculated with $20 \mu \mathrm{L}$ of a 0.1 O.D. $595 \mathrm{~nm}$ pre-inoculum (please see Table 1).

To assess the reversibility of the $\mathrm{NaCl}$-tolerance phenotype, after exposure to $\mathrm{NaCl}$ for $30 \mathrm{~d}$ period, $20 \mu \mathrm{l}$ of each population were used to inoculate LB medium and cultured for 16 days (Et-R1 to Et-R5).

After the long-term exposure period ( 46 days), the sensitivity of the 15 clonal populations ( 5 clonal populations $\times 3$ exposure scenarios) was determined by exposing them to six concentrations of $\mathrm{NaCl}(5$ $\mathrm{g} / \mathrm{L} ; 10 \mathrm{~g} / \mathrm{L} ; 15 \mathrm{~g} / \mathrm{L} ; 20 \mathrm{~g} / \mathrm{L} ; 25 \mathrm{~g} / \mathrm{L} ; 35 \mathrm{~g} / \mathrm{L}$ ) plus a control (LB medium), in triplicate. Exposure occurred for 120 hours at $120 \mathrm{rpm}$, at $28 \pm 1^{\circ} \mathrm{C}$ and a photoperiod of $16: 8$ hours light. At the end of the assay the O.D. was measured at $595 \mathrm{~nm}$ in a UV-vis Spectrophotometer (UVmini-1240, UV-vis Spectrophotometer, Shimadzu). The $\mathrm{pH}$, conductivity and salinity were measured in all tested solutions with multiparameter equipment (WTW Multi 3410 SET C 2FD45C). 
The populations of $E$. toletana, after exposure to the three treatments, were stored at $-80^{\circ} \mathrm{C}$ in NB-medium with $15 \%$ glycerol.

\section{Bacterial metabolic analysis: biolog "fingerprint" analysis}

The influence of long-term exposure to increased salinity on the metabolic degradation of carbon compounds (through Biolog Plates) of the E. toletana clonal populations (Et-LB, Et-NaCl and Et-R) was also assessed. For this, the Biolog method analysis was carried out, following the instructions of GEN III MicroPlate ${ }^{\mathrm{TM}}$ protocol test although the incubation time was extended for $48 \mathrm{~h}$ at $28 \pm 1^{\circ} \mathrm{C}$, following the bacterium optimal conditions of growth. The turbidity of the inoculum of each population was set at the same value (65\%) at the beginning of the incubation. Five replicates of each population were conducted. The optical densities, as surrogates of metabolic activity, were measured after time $0 \mathrm{~h}, 16 \mathrm{~h}, 24 \mathrm{~h}$ and $48 \mathrm{~h}$.

Biolog (Biolog Inc., Hayward, CA, USA) is commonly used to differentiate microbial communities and to identify bacterial isolates, based on 94 phenotypic tests (Stefanowicz, 2006; Guckert et al., 1996). Here it was used to compare the capacity of $E$. toletana populations to metabolize diverse carbon sources following its previously exposure to different salinity conditions. Each Biolog plate (96-well plate) is constituted by two groups of substances, one is constituted by 71 carbon substrates plus a negative control without any carbon source, remaining colorless. From the 71 carbon substrates 4 main groups are distinguish: sugars, amino acids, hexose acids and carboxylic acids, esters and fatty acids. The other is composed of 23 chemical substances (e.g. hydrogen ions, $\mathrm{NaCl}$, lactic acid) that may potentially inhibit the growth of bacteria plus a positive control, which correspond to a reference source for chemical sensitivity causing no inhibition in growth.

\section{Fingerprinting for molecular typing: BOX-PCR}

To search for genomic alterations, a molecular typing BOX-PCR strategy was applied. Cells from each clonal population of E. toletana (Et-LB, Et-NaCl, Et-R) were suspended in $20 \mu \mathrm{L}$ of sterilized water and used as template in the PCR reactions. PCR reactions $(25 \mu \mathrm{L})$ contained $6.25 \mu \mathrm{L}$ of NZYtaq $2 \mathrm{X}$ green Master

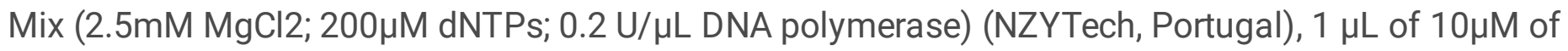
primer BOX A1R (5'-CTA CGG CAA GGC GAC GCT GAC G-3'), $1 \mu \mathrm{L}$ of the cell suspension and nuclease-free water. The program set in a BioRad $\mathrm{C} 1000$ Touch $^{\mathrm{TM}}$ Thermal Cycler was $95^{\circ} \mathrm{C}-7^{\prime} ; 30$ cycles at $94^{\circ} \mathrm{C}-1^{\prime}$, $53^{\circ} \mathrm{C}-1^{\prime}, 65^{\circ} \mathrm{C}-8^{\prime}$ and $65^{\circ} \mathrm{C}-16^{\prime}$. PCR products were loaded in agar gels and separated by electrophoresis in $1 \times$ TAE at $80 \mathrm{~V}$ for 3 hours.

\section{Statistical analysis}

The results obtained in the sensitivity assay were adjusted to a logistic model to calculate the concentrations of $\mathrm{NaCl}$ causing 10,20 and $50 \%$ of growth inhibition of E. toletana $\left(\mathrm{EC}_{10}, \mathrm{EC}_{20}\right.$ and $\left.\mathrm{EC}_{50}\right)$ and the respective $95 \%$ confidence limits. These calculations were made via StatSoft, Inc. (2007) STATISTICA. To identify significant effects of $\mathrm{NaCl}$ exposure on the $E$. toletana populations sensitivity, a two-way variance analysis (ANOVA) was performed followed by the multicomparison Dunnett's test. 
The data obtained in the metabolic assay was analyzed with a repeated-measure ANOVA to assess differences in the consumption of the different carbon substrate over time, within the same clonal population (Et-LB, Et-NaCl or Et-R). To identify differences between the controls and the carbon substrates or the inhibitory chemical substances a one-way ANOVA was carried out for each clonal population followed by the Dunnett's multicomparison test.

The ANOVA assumptions were tested with Kolmogorov-Smirnov test for normality and Barttlet's test for variances homogeneity. These analyses were made by using the SigmaPlot Inc. (2012) Systat Software.

\section{Results}

\section{Sensitivity assay}

The E. toletana growth rate at $28^{\circ} \mathrm{C}$ and $180 \mathrm{rpm}$ conditions was $0.0527^{-1}$ in LB medium in the exponential phase.

The measured parameters of $\mathrm{pH}$, conductivity and salinity of the control medium and the medium with $\mathrm{NaCl}$ concentrations are shown in Table 2. The values of $\mathrm{pH}$ were very similar among treatments, ranging from 5.20 to 5.31 . As expected, conductivity and salinity increased with increasing $\mathrm{NaCl}$ concentrations, varying from 11.5 (control) to $62.6 \mathrm{mS} / \mathrm{cm}(35 \mathrm{~g} / \mathrm{L} \mathrm{NaCl})$ and from 6.5 to 42.1 , respectively. Values of $\mathrm{pH}$, conductivity and salinity of each tested concentration are presented in table 2 .

The results obtained with the sensitivity assay carried out with the Et-LB, Et-NaCl and Et-R populations of E. toletana revealed a significant reduction in optical density with exposure to the different tested concentrations of $\mathrm{NaCl}(p<0.05$ Fig. 1). An exception occurred with Et-NaCl exposed to at 10 and $15 \mathrm{~g} / \mathrm{L}$, where no significant effects, comparatively to the control, were observed in O.D ( $p>0.05$; Fig. 1). Furthermore, the populations from the three long-term exposure scenarios exhibited a similar sensitivity to $\mathrm{NaCl}$ for most tested concentrations: significant differences between Et-NaCl and Et-LB or Et-R were observed at 10 and $15 \mathrm{~g} / \mathrm{L}$ of $\mathrm{NaCl}$ (Tukey'stest: $\mathrm{p}<0.05$ ). Differences between Et-LB and Et-R were not observed for none of the $\mathrm{NaCl}$ tested concentrations (Fig.1).

The concentrations causing 10, 20 and $50 \%$ of effect in E. toletana populations growth are shown in Table 3. The $\mathrm{EC}_{10}, \mathrm{EC}_{20}$ and $\mathrm{EC}_{50}$ were always higher for $\mathrm{Et}-\mathrm{NaCl}$, however the confidence limits of these parameters overlap with the ones of Et-LB and Et-R, indicating a similar tolerance of the three clonal populations to $\mathrm{NaCl}$

\section{Biolog's carbon compounds metabolic analysis}

In Figure 2 are presented the optical densities measured for the long-term exposed populations of $E$. toletana (Et-LB, Et-NaCl and Et-R), for 71 carbon compounds and 23 chemicals to test sensitivity, after an incubation period of $0,16,24$ and 48 hours. 
At time $0 \mathrm{~h}$ the 9 clonal populations (three of each treatment: Et-LB, Et-NaCl and Et-R) presented an optical density below 0.5 , except for Et-R for the sodium bromate. Significant changes, in the measured optical densities, were observed over time for the nine established clonal populations of E. toletana. For Et-LB a significant increase in the optical density for the wells corresponding to the 71 carbon substrates, 23 chemical substances and controls was observed for all observation times $(p<0.05)$, while for Et-NaCl and Et-R such a significant difference was observed among all observation times except between $16 \mathrm{~h}$ and $24 \mathrm{~h}$ and between $24 \mathrm{~h}$ and $48 \mathrm{~h}$, respectively (Fig. 2). Overall, at time Oh, the O.D. levels within Et-NaCl, EtLB and Et-R were not significantly different running from the same initial conditions (Fig. 2; p>0.05). At the other three observation times the O.D. of the clonal populations of E. toletana were similar (Fig. 2).

When comparing the consumption of the different carbon substrates among the populations of $E$. toletana (e.g. Et-LB, Et-NaCl and Et-R), after 0, 16, 24 and 48h incubation period, significant differences in specific carbon substrates were observed between Et-LB and Et-R, between Et-NaCl and Et-R, but not between Et-LB and Et-NaCl for any substrate $(p>0.05)$. Et-LB populations showed a significantly higher consumption of D-Raffinose, a-D-Glucose, D-Mannose, Pectin and D-Maltose, than Et-R populations $(p<0.05)$. Et-NaCl showed a higher consumption of a-Amino-Butryric Acid, $\beta$-Hydroxy-Butyric Acid, DMelibiose, D-Raffinose, a-D-Glucose, D-Mannose, D-Mannose, than Et-R while an opposite result was observed for Pectin $(p<0.05)$.

Significant changes in the consumption rate of the 71 carbon sources, relatively to the respective carbon substrate control of the Biolog's Plate, were observed for 11 of them, after the $48 \mathrm{~h}$ incubation period $(p<0.05$; Fig. 3). In Figure 3 are presented the optical densities (used as surrogates for carbon substrates consumption), measured for Et-LB, Et-NaCl and Et-R in the control and in the carbon substrate sources that showed significant differences relatively to the respective control. The following carbon sources were consumed at significantly different rates relatively to the respective control: D-Mannose, a- D- Glucose, DFructose and $1 \%$ of Sodium Lactate for the clonal lineage Et-LB; D-Mannose, a- D- Glucose, D-Fructose, $1 \%$ of Sodium Lactate, $\beta$ - Hydroxy-Butyric-Acid, L-Galactonic, Glycyl-L-Proline, D-Sorbitol, Tween 40, DRaffinose and D-Lactic Acid for the clonal lineage Et- NaCl; and D-Mannose, $\mathrm{a}$ - D- Glucose, $1 \%$ of Sodium Lactate, $\beta$-Hydroxy-Butyric-Acid, L-Galactonic, Glycyl-L-Proline, and D-Sorbitol for clonal lineage Et-R. Overall, the consumption of these substrates increased relatively to the respective control, except for DLactic acid in Et-NaCl and a-D-Glucose in Et-R, which significantly decrease. The three clonal lineages of E. toletana exhibited higher consumptions of D-Mannose, a-D-Glucose and $1 \%$ of sodium lactate, than the consumptions registered in the respective controls.

\section{Fingerprinting for molecular typing: BOX-PCR}

The typing method, to investigate genomic alterations, revealed no relevant differences among populations (Fig. 4).

\section{Discussion}


Long-term exposure of an Erwinia toletana strain to low levels of $\mathrm{NaCl}$ allowed the bacterium to acquire a slightly higher tolerance to this chemical. After being exposed, for 46 days, to the $\mathrm{EC}_{10}$ for $\mathrm{NaCl}(18 \mathrm{~g} / \mathrm{L})$, the $\mathrm{EC}_{20,120 \mathrm{~h}}$ for $\mathrm{NaCl}$ increased from $5 \mathrm{~g} / \mathrm{L}$ to $16.3 \mathrm{~g} / \mathrm{L}$. These results are in line with other works that have already reported the capacity of bacteria to acquire increased tolerance to salinity (e.g., Dhar et al. 2011; Zhou et al. 2013; Wang et al. 2019), although, different strains can respond differently to the same conditions of exposure. Such increased tolerance to salt stress has been associated with a set of physiological responses. The biosynthesis of osmolytes and intracellular accumulation of mixtures of organic compounds (aiming to maintain the cytoplasm in an isosmotic state), has been reported to be one of the major pathways to cope with salt stress (Oren 2008; Ma et al. 2010), mainly in Gram-negative bacteria (Baumann and Marschner 2013). Osmolytes are compatible solutes with osmoprotectants properties produced by bacteria without disturbing cell functions (Saum and Müller 2007; Qurashi and Sabri 2013). An 8-fold accumulation of glutamate and of alanine (1.8-fold) was observed in the bacterium Desulfovibrio vulgaris after being exposed for 100-h to $250 \mathrm{mM} \mathrm{NaCl}$ (He et al., 2010). Within the genus Erwinia, Touzé et al. (2004) detected that E. chrysanthemi accumulated mainly glutamine when exposed to high salinity levels, while alpha-glucosylglycerate and glutamate were the predominant osmolytes when exposure occurred at low salt concentrations. It is then hypothesized that in the present work, one of the major mechanisms involved in the observed increase in salinity tolerance by $E$. toletana involved the production and intracellular accumulation of a mixture of osmolytes.

Another important mechanism identified to be involved in tolerance acquisition to salinity includes changes in the lipid composition of the cell membrane. The increase in unsaturated branched fatty acids, in bacteria exposed to salt stress, was associated with higher membrane fluidity (e.g. Zhou et al., 2013). In the present work, no direct evidence for the occurrence of this mechanism in $\mathrm{NaCl}$-exposed $E$. toletana was observed although it could be occurring for the recovered $E$. toletana due to its significant difference of carbon substrates consumption from the Et-LB and Et-R. The common carbon sources consumed by all populations: D-Mannose and a-D-Glucose, which are majorly related with optimal conditions for bacteria growth and adhesion (Schröder et al. 1994; Huang et al. 2015; Jahnke et al. 2016), and Sodium Lactate involved in metabolism, cellular signaling and depress water activity (Wang et al. 2015; Schelegueda et al. 2016). These carbon compounds seemed to be essential not just to the cell growth but also adaptation to salinity stress in the case of Et- $\mathrm{NaCl}$ and Et-R.

Furthermore, microorganisms can use and metabolize different types of carbon compounds to acquire energy and to grow (Görke and Stülke 2008). Energy can be obtained from the converse of organic compounds through different metabolic pathways as glycolysis, pentose phosphate pathway, EntnerDuodoroff pathwayamong others, depending on the organism, medium surrounding or stress (caused by infection for example), different or single-selective metabolic pathways can be activated to cope with these conditions (Muñoz-elías and Mckinney 2006). In this present case and as earlier mentioned, it is possible to observe distinct responses to different carbon substrates when the bacterium was exposed to the different conditions. Along time, the populations tested revealed different patterns, the Et-LB exposed continuously to LB medium grew always in a constant form, greater increasing in some specific 
substrates what can be carbons compounds important to cell growth. The Et-NaCl revealed the most different pattern, from the three treatments, it had a faster carbon substrate consumption, demonstrated mostly at 0 and $24 \mathrm{~h}$ of the inoculation and follow this higher growth it seems to have a decrease at $48 \mathrm{~h}$ what can be due to carbon substrates depletion. For the sensitivity compounds of the test, it could be occurring some tolerance acquirement once it continues to have greater optical density. Moreover, the Et$\mathrm{NaCl}$ long-term exposed showed higher consumption of a higher diversity of carbon sources. This could be related with the activation of metabolic pathways involving enzymes associated with the use of those carbon sources to produce energy. This extra need for energy could be associated with the activation of detoxification mechanisms, like the production of osmolytes.

For the Et-R it was possible to observe an in-between pattern, which may reveal some tolerance acquired by the isolate, displaying a similar growth pattern as Et-LB, which were not exposed to $\mathrm{NaCl}$ and in this manner, the need to repair, grow, metabolize and restore the cell membrane as it can be occurring with Et$\mathrm{NaCl}$ is not observable in a strong way. Grattieri and colleagues (2019) also tested the capacity of adaptation of Rhodobacter capsulatos to increasing salinity $(0-25 \mathrm{~g} / \mathrm{L}$ of $\mathrm{NaCl})$. The authors suggest that the bacterium mechanism to adapt to higher salinity relies in increasing proteins expression. Associated with this mechanism is the synthesis of compatible osmotic solutes such as trehalose and the uptake of compatible solutes such as glycine betain and potassium from the extracellular medium.

Conversely, other energetic demanding mechanisms could also have been activated to deal with osmotic stress. For example, the increase of cation exchange proteins expression or other mechanisms of active transport across the cell membrane. Zhou et al. (2013) reported an increase in basal expression of the $\mathrm{Na}^{+} / \mathrm{H}^{+}$antiporter and of a cation efflux protein encoding genes in response to $\mathrm{NaCl}$ stress in bacteria.

The results obtained for $E$. toletana, after being able to apparently recover for 16 days from $\mathrm{NaCl}$ exposure, also support this hypothesis since, the differences in the used of carbon sources between Et-R and Et-LB were fewer than between Et-NaCl and Et-LB, suggesting that the bacteria, in the absence of salt stress, was restoring its basal energetic metabolism. Possibly, if the period of continued exposure of $E$. toletana to LB medium, following for more 16 days of exposure to $\mathrm{NaCl}$ was longer than 16 days, a complete recovery of the basal energetic metabolism would have occurred. Additional knowledge is needed to understand the specific mechanisms that are triggered by E. toletana to cope with salinity. Nevertheless, considering the EC50 for salinity tolerance of the studied bacterium, E. toletana may be a potential candidate for amphibian's skin bioaugmentation approaches, as has been already described for other microrganisms (Becker et al. 2009; McKenzie et al. 2012; Woodhams et al. 2014).

\section{Conclusion}

Erwinia toletana was capable of slightly increasing its tolerance to low levels of salinity after a long-term exposure to this stress. This result was probably associated with membrane cell physiological alterations that were reversible after transferring the bacteria to LB medium. 
This ability of non-pathogens to acquire tolerance and eventually multiple tolerance to environmental stress may constitute a promising tool in bioaugmentation in amphibian's skin, aiming the improvement of the tolerance of these organisms to chemical contamination.

\section{Declarations}

\section{Ethical Approval and consent to participate}

Not applicable

\section{Consent for publication}

The authors have no conflict of interest to be reported, and the manuscript was approved by all authors for submission. Furthermore, I declare, on behalf of co-authors, that this work has original research that has not been published previously, and not under consideration for publication elsewhere, in whole or in part.

\section{Competing interests}

Not applicable

\section{Availability of data and material}

The datasets from the current study are available from the corresponding author on request.

\section{Authors' contributions}

Antonieta Gabriel: conceptualization, methodology, formal analysis, investigation, writing: original draft. Sara Costa: methodology, investigation. Isabel Henriques: conceptualization, writing review and editing, resources. Isabel Lopes: conceptualization, funding acquisition, resources, supervision, writing: review and editing project administration.

\section{Acknowledgements and Funding}

This work was supported by the project Generosi (PTDC/BIA-BIC/3488/2012 - FCOMP01-0124-FEDER028278) funded by FEDER, through COMPETE2020 - Programa Operacional Competitividade e Internacionalização (POCI), and by national funds (OE) and by CESAM (UIDB/50017/2020 + UIDP/50017/2020), through FCT/MCTES through national funds.

\section{References}

1. Baumann K, Marschner $P$ (2013) Effects of salinity on microbial tolerance to drying and rewetting. Biogeochemistry 112:71-80. https://doi.org/10.1007/s10533-011-9672-1 
2. Becker MH, Brucker RM, Schwantes CR, et al (2009) The bacterially produced metabolite violacein is associated with survival of amphibians infected with a lethal fungus. Appl Environ Microbiol 75:6635-6638. https://doi.org/10.1128/AEM.01294-09

3. Beebee TJC, Griffiths R (2005) The amphibian decline crisis: A watershed for conservation biology? Biol Conserv 125:271-285. https://doi.org/10.1016/j.biocon.2005.04.009

4. Bernabò I, Bonacci A, Coscarelli F, et al (2013) Effects of salinity stress on Bufo balearicus and Bufo bufo tadpoles: Tolerance, morphological gill alterations and $\mathrm{Na}+/ \mathrm{K}+-\mathrm{ATP}$ ase localization. Aquat Toxicol 132-133:119-133. https://doi.org/10.1016/j.aquatox.2013.01.019

5. Bletz MC, Loudon AH, Becker MH, et al (2013) Mitigating amphibian chytridiomycosis with bioaugmentation: characteristics of effective probiotics and strategies for their selection and use. Ecol Lett 16:807-820. https://doi.org/10.1111/ele.12099

6. Cañedo-Argüelles M, Kefford BJ, Piscart C, et al (2013) Salinisation of rivers: An urgent ecological issue. Environ Pollut 173:157-167. https://doi.org/10.1016/j.envpol.2012.10.011

7. Colombo BM, Scalvenzi T, Benlamara S, Pollet N (2015) Microbiota and Mucosal Immunity in Amphibians. Front Immunol 6:1-15. https://doi.org/10.3389/fimmu.2015.00111

8. Costa S, Lopes I, Proença DN, et al (2016) Diversity of cutaneous microbiome of Pelophylax perezi populations inhabiting different environments. Sci Total Environ 572:995-1004. https://doi.org/10.1016/j.scitotenv.2016.07.230

9. Dhar R, Sägesser R, Weikert C, et al (2011) Adaptation of Saccharomyces cerevisiae to saline stress through laboratory evolution. J Evol Biol 24:1135-1153. https://doi.org/10.1111/j.14209101.2011.02249.x

10. Geider K, Auling G, Du Z, et al (2006) Erwinia tasmaniensis sp. nov., a non-phytopathogenic bacterium from apple and pear trees. Int J Syst Evol Microbiol 56:2937-2943. https://doi.org/10.1099/ijs.0.64032-0

11. Görke B, Stülke J (2008) Carbon catabolite repression in bacteria: many ways to make the most out of nutrients. Nat Rev Microbiol 6:613-624. https://doi.org/10.1038/nrmicro1932

12. Grattieri M, Beaver K, Gaffney EM, Minteer SD (2019) Tuning purple bacteria salt-tolerance for photobioelectrochemical systems in saline environments. Faraday Discuss 215:15-25. https://doi.org/10.1039/c8fd00160j

13. Harris RN, Brucker RM, Walke JB, et al (2009) Skin microbes on frogs prevent morbidity and mortality caused by a lethal skin fungus. ISME J 3:818-824. https://doi.org/10.1038/ismej.2009.27

14. Hart BT, Bailey P, Edwards R, et al (1990) Effects of salinity on river, stream and wetland ecosystems in Victoria, Australia. Water Res 24:1103-1117. https://doi.org/10.1016/0043-1354(90)90173-4

15. He H, Chen Y, Li X, et al (2016) Influence of salinity on microorganisms in activated sludge processes: A review. Int Biodeterior Biodegradation 1-8. https://doi.org/10.1016/j.ibiod.2016.10.007

16. Holden WM, Hanlon SM, Woodhams DC, et al (2015) Skin bacteria provide early protection for newly metamorphosed southern leopard frogs (Rana sphenocephala) against the frog-killing fungus, 
Batrachochytrium dendrobatidis. Biol Conserv 187:91-102.

https://doi.org/10.1016/j.biocon.2015.04.007

17. Huang CJ, Lin H, Yang JX (2015) A robust method for increasing Fc glycan high mannose level of recombinant antibodies. Biotechnol Bioeng 112:1200-1209. https://doi.org/10.1002/bit.25534

18. Jahnke JP, Terrell JL, Smith AM, et al (2016) Influences of adhesion variability on the 'living' dynamics of filamentous bacteria in microfluidic channels. Molecules 21:. https://doi.org/10.3390/molecules21080985

19. Kirwan ML, Megonigal JP (2013) Tidal wetland stability in the face of human impacts and sea-level rise. Nature 504:53-60. https://doi.org/10.1038/nature12856

20. Kueneman JG, Parfrey LW, Woodhams DC, et al (2014) The amphibian skin-associated microbiome across species, space and life history stages. Mol Ecol 23:1238-1250.

https://doi.org/10.1111/mec. 12510

21. Ma Y, Galinski EA, Grant WD, et al (2010) Halophiles 2010: Life in Saline Environment Halophiles 2010: Life in Saline Environments. Appl Environ Microbiol 76:6791-6981. https://doi.org/10.1128/AEM.01868-10

22. Margesin R, Schinner F (2001) Potential of halotolerant and halophilic microorganisms for biotechnology. Extremophiles 73-83. https://doi.org/10.1007/s007920100184

23. Mccoy MW (2017) Adaptive responses to salinity stress across multiple life stages in anuran amphibians. 1-16. https://doi.org/10.1186/s12983-017-0222-0

24. McKenzie VJ, Bowers RM, Fierer N, et al (2012) Co-habiting amphibian species harbor unique skin bacterial communities in wild populations. ISME J 6:588-596.

https://doi.org/10.1038/ismej.2011.129

25. Miliute I, Buzaite O, Baniulis D, Stanys V (2015) Bacterial endophytes in agricultural crops and their role in stress tolerance: a review. Zemdirbyste 102:465-478. https://doi.org/10.13080/z-

a.2015.102.060

26. Mills AAS, (Bud) Platt HW, Hurta RAR (2006) Sensitivity of Erwinia spp. to salt compounds in vitro and their effect on the development of soft rot in potato tubers in storage. Postharvest Biol Technol 41:208-214. https://doi.org/10.1016/j.postharvbio.2006.03.015

27. Mulamba T, Bacopoulos P, Kubatko EJ, Pinto GF (2019) Sea-level rise impacts on longitudinal salinity for a low-gradient estuarine system. Clim Change 152:533-550. https://doi.org/10.1007/s10584-019-02369-x

28. Muñoz-elías EJ, Mckinney JD (2006) Microreview Carbon metabolism of intracellular bacteria. 8:1022. https://doi.org/10.1111/j.1462-5822.2005.00648.x

29. Oren A (2008) Microbial life at high salt concentrations: phylogenetic and metabolic diversity. Saline Systems 13:1-13. https://doi.org/10.1186/1746-1448-4-2

30. Payen S, Basset-Mens C, Núñez M, et al (2016) Salinisation impacts in life cycle assessment: a review of challenges and options towards their consistent integration. Int J Life Cycle Assess 21:577-594. https://doi.org/10.1007/s11367-016-1040-x

Page 12/18 
31. Qurashi AW, Sabri AN (2013) Osmolyte accumulation in moderately halophilic bacteria improves salt tolerance of chickpea. Pakistan J Bot 45:1011-1016

32. Rojas A, García de los Rios JE, Fischer-Le Saux M, et al (2004a) Erwinia toletana sp. nov., associated with Pseudomonas savastanoi-induced tree knots. Int J Syst Evol Microbiol 54:2217-2222. https://doi.org/10.1099/ijs.0.02924-0

33. Rojas AM, García de los Rios JE, Fischer-Le Saux M, et al (2004b) Erwinia toletana sp. nov., associated with Pseudomonas savastanoi-induced tree knots. Int J Syst Evol Microbiol 54:22172222. https://doi.org/10.1099/ijs.0.02924-0

34. Saum SH, Müller V (2007) Salinity-dependent switching of osmolyte strategies in a moderately halophilic bacterium: Glutamate induces proline biosynthesis in Halobacillus halophilus. J Bacteriol 189:6968-6975. https://doi.org/10.1128/JB.00775-07

35. Schelegueda LI, Zalazar AL, Gliemmo MF, Campos CA (2016) Inhibitory effect and cell damage on bacterial flora of fish caused by chitosan, nisin and sodium lactate. Int J Biol Macromol 83:396-402. https://doi.org/10.1016/j.ijbiomac.2015.11.033

36. Schröder C, Selig M, Schönheit P (1994) Glucose fermentation to acetate, CO2 and H2 in the anaerobic hyperthermophilic eubacterium Thermotoga maritima: involvement of the EmbdenMeyerhof pathway. Arch Microbiol 161:460-470. https://doi.org/10.1007/BF00307766

37. Silva DP, Castañeda-Ojeda MP, Moretti C, et al (2014) Bacterial multispecies studies and microbiome analysis of a plant disease. Microbiol (United Kingdom) 160:556-566. https://doi.org/10.1099/mic.0.074468-0

38. Touzé T, Goude R, Georgeault S, et al (2004) Erwinia chrysanthemi $O$ antigen is required for betaine osmoprotection in high-salt media. J Bacteriol 186:5547-5550. https://doi.org/10.1128/JB.186.16.5547-5550.2004

39. Venâncio C, Ribeiro R, Lopes I (2020) Active emigration from climate change-caused seawater intrusion into freshwater habitats. Environ Pollut 258.. https://doi.org/10.1016/j.envpol.2019.113805

40. Waditee-Sirisattha R, Kageyama H, Takabe $T$ (2016) Halophilic microorganism resources and their applications in industrial and environmental biotechnology. AlMS Microbiol 2:42-54. https://doi.org/10.3934/microbiol.2016.1.42

41. Wang $H$, Wang $L$, Yang $H$, et al (2015) Comparative proteomic insights into the lactate responses of halophilic salinicoccus roseus W12. Sci Rep 5:1-11. https://doi.org/10.1038/srep13776

42. Woodhams D, Bletz M, Kueneman J, McKenzie V (2016) Managing Amphibian Disease with Skin Microbiota. Trends Microbiol 24:161-164. https://doi.org/10.1016/j.tim.2015.12.010

43. Woodhams DC, Brandt $H$, Baumgartner $S$, et al (2014) Interacting symbionts and immunity in the amphibian skin mucosome predict disease risk and probiotic effectiveness. PLoS One 9:. https://doi.org/10.1371/journal.pone.0096375

44. Zhou A, Baidoo E, He Z, et al (2013) Characterization of $\mathrm{NaCl}$ tolerance in Desulfovibrio vulgaris Hildenborough through experimental evolution. ISME J 7:1790-1802. https://doi.org/10.1038/ismej.2013.60 


\section{Tables}

Table 1 Summary of the long-term exposure procedure for the clonal populations of Erwinia toletana EtLB, Et-NaCl and Et-R

\begin{tabular}{|c|c|c|c|c|}
\hline $\begin{array}{l}\text { Pre- } \\
\text { Inoculum }\end{array}$ & $\begin{array}{l}\text { Clonal } \\
\text { populations } \\
\text { ( } n=5 \text { for } \\
\text { each } \\
\text { condition) }\end{array}$ & Exposure scenario & $\begin{array}{l}\text { Type of medium for the long- } \\
\text { term exposures ( } 24 \text { wells-plate) }\end{array}$ & $\begin{array}{l}\text { Conditions of } \\
\text { the exposure }\end{array}$ \\
\hline \multirow[t]{3}{*}{$\begin{array}{l}20 \mu \mathrm{L} \text { of } \\
\text { a } 0.1 \\
\text { O.D. } 595 \mathrm{~nm} \\
\text { culture }\end{array}$} & Et- LB & $\begin{array}{l}\text { Continuous } \\
\text { exposure to LB } \\
\text { medium }\end{array}$ & 46 days in $2 \mathrm{~mL}$ LB medium & \multirow[t]{3}{*}{$\begin{array}{l}120 \mathrm{rpm} \\
28 \pm 1^{\circ} \mathrm{C} ; \\
\text { photoperiod } \\
16: 8 \mathrm{~h} \text { - light: } \\
\text { dark }\end{array}$} \\
\hline & $\mathrm{Et}-\mathrm{NaCl}$ & $\begin{array}{l}\text { Continuous } \\
\text { exposure to } \mathrm{NaCl}\end{array}$ & $\begin{array}{l}46 \text { days in } 2 \mathrm{~mL} \mathrm{LB} \text { medium } \\
\text { with } 18 \mathrm{~g} / \mathrm{L} \text { of } \mathrm{NaCl}\end{array}$ & \\
\hline & Et- $R$ & $\begin{array}{l}\text { Exposure to } \mathrm{NaCl} \\
\text { medium with } \\
\text { subsequent transfer } \\
\text { to LB medium }\end{array}$ & $\begin{array}{l}30 \text { days in } 2 \mathrm{~mL} \mathrm{LB} \text { medium } \\
\text { with } 18 \mathrm{~g} / \mathrm{L} \text { of } \mathrm{NaCl} \text { and } \\
\text { transferred for } 16 \text { days to } 2 \mathrm{~mL} \\
\text { LB medium. }\end{array}$ & \\
\hline
\end{tabular}

Table 2 Parameters of $\mathrm{pH}$, conductivity and salinity measured in the control (medium LB) and in the $\mathrm{NaCl}$ concentrations to which E. toletana was exposed

\begin{tabular}{|lllllllll|}
\hline $\mathbf{N a C l}(\mathbf{g} / \mathrm{L})$ & $\mathbf{0}(\mathrm{Ctr})$ & $\mathbf{5}$ & $\mathbf{1 0}$ & $\mathbf{1 5}$ & $\mathbf{2 0}$ & $\mathbf{2 5}$ & $\mathbf{3 0}$ & $\mathbf{3 5}$ \\
$\mathbf{p H}$ & 5.24 & 5.31 & 5.23 & 5.20 & 5.21 & 5.29 & 5.27 & 5.22 \\
& & & & & & & & \\
\hline Conductivity $(\mathrm{mS} / \mathrm{cm})$ & 11.5 & 23.9 & 28.0 & 34.7 & 41.2 & 50.8 & 56.3 & 62.6 \\
\hline Salinity & & & & & & & & \\
\hline
\end{tabular}

Table 3 Values of the $\mathrm{NaCl}$ concentrations $(\mathrm{g} / \mathrm{L})$ causing 10,20 and $50 \%\left(\mathrm{EC}_{10}, \mathrm{EC}_{20}\right.$ and $\mathrm{EC}_{50}$, respectively) of growth inhibition in the three clonal populations of the bacterium Erwinia toletana. Et-LB 
-E. toletana exposed for 46 days to medium LB; Et- $\mathrm{NaCl}-$ E. toletana exposed for 46 days to $18 \mathrm{~g} / \mathrm{L}$ of $\mathrm{NaCl}$; and Et- R - E. toletana exposed for 30 days to $18 \mathrm{~g} / \mathrm{L}$ of $\mathrm{NaCl}$ and subsequently transferred for 16 days to $\mathrm{LB}$ medium a - The $\mathrm{EC}_{10}$ could not be computed.

\begin{tabular}{|llll|}
\hline Clonal populations & $\mathrm{EC}_{10}$ & $\mathrm{EC}_{20}$ & $\mathrm{EC}_{50}$ \\
\hline $\mathrm{Et}-\mathrm{LB}$ & $2.10[-2.30-6.51]$ & $5.08[-2.2-12.4]$ & $22.5[8.64-36.4]$ \\
\hline $\mathrm{Et}-\mathrm{NaCl}$ & $11.3[2.79-19.9]$ & $16.3[8.15-24.5]$ & $30.3[23.2-37.4]$ \\
\hline $\mathrm{Et}-\mathrm{R}$ & $\mathrm{a}$ & $3.61[1.96-5.27]$ & $26.1[19.3-32.9]$ \\
\hline
\end{tabular}

\section{Figures}

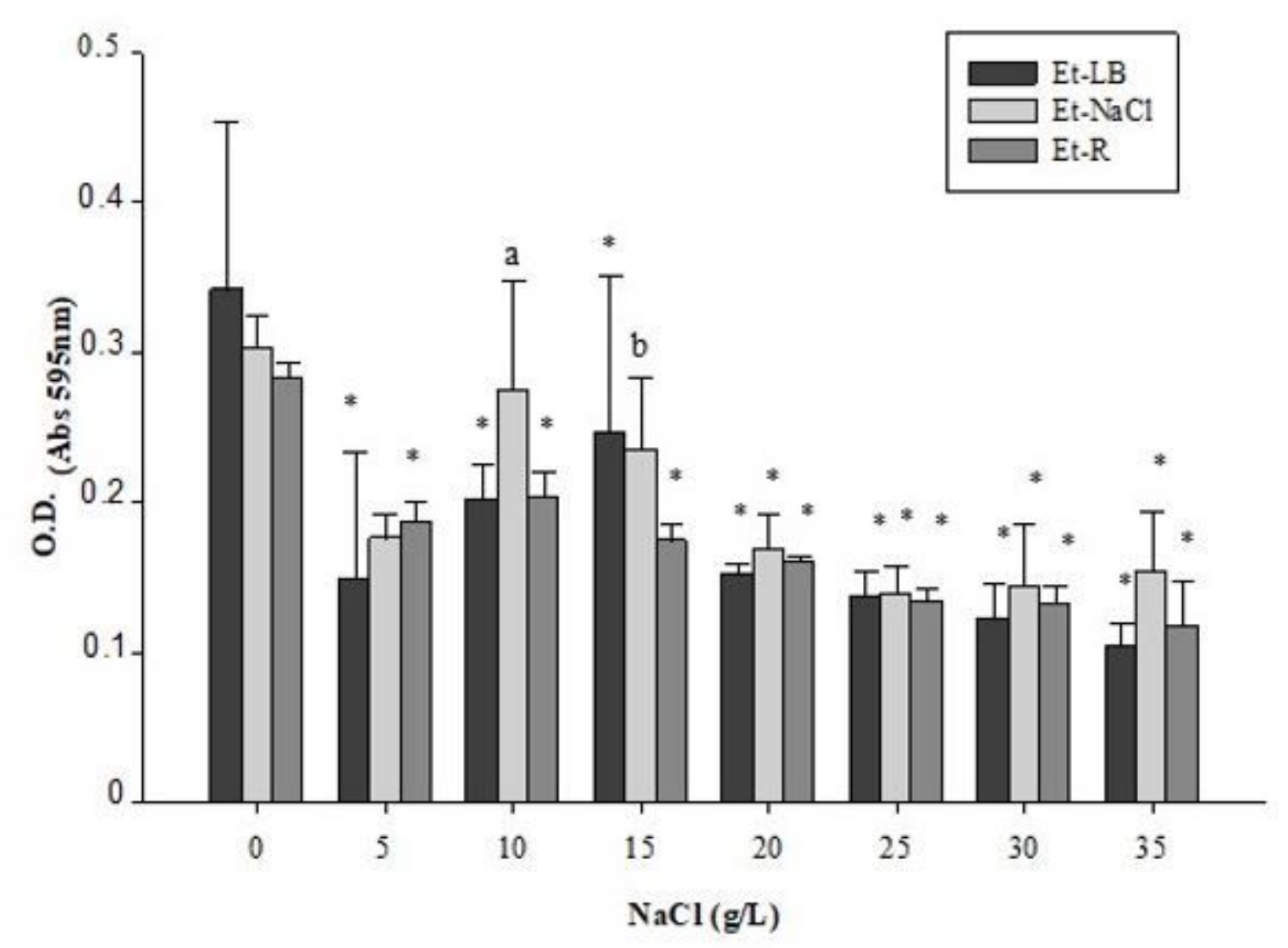

Figure 1

Sensitivity of Erwinia toletana populations to $\mathrm{NaCl}$ measured as average optical density of three replicates (O.D) and standard deviation (error bars). Et-LB - populations exposed for 46 days to LB 
medium ( $n=5), E t-N a C l$ - populations exposed for 46 days to $18 \mathrm{~g} / \mathrm{L}$ of $\mathrm{NaCl}(\mathrm{n}=5), \mathrm{Et}-\mathrm{R}$ - populations exposed to $\mathrm{NaCl}$ and transferred to LB medium again $(n=5)$. Legend: $a, b$ - significant differences between $\mathrm{Et}-\mathrm{NaCl}$ versus Et-LB and $\mathrm{Et}-\mathrm{NaCl}$ versus Et-R within each $\mathrm{NaCl}$ concentration and * significant differences comparatively to the respective control $(p<0.05)$. Error bars correspond to standard deviation

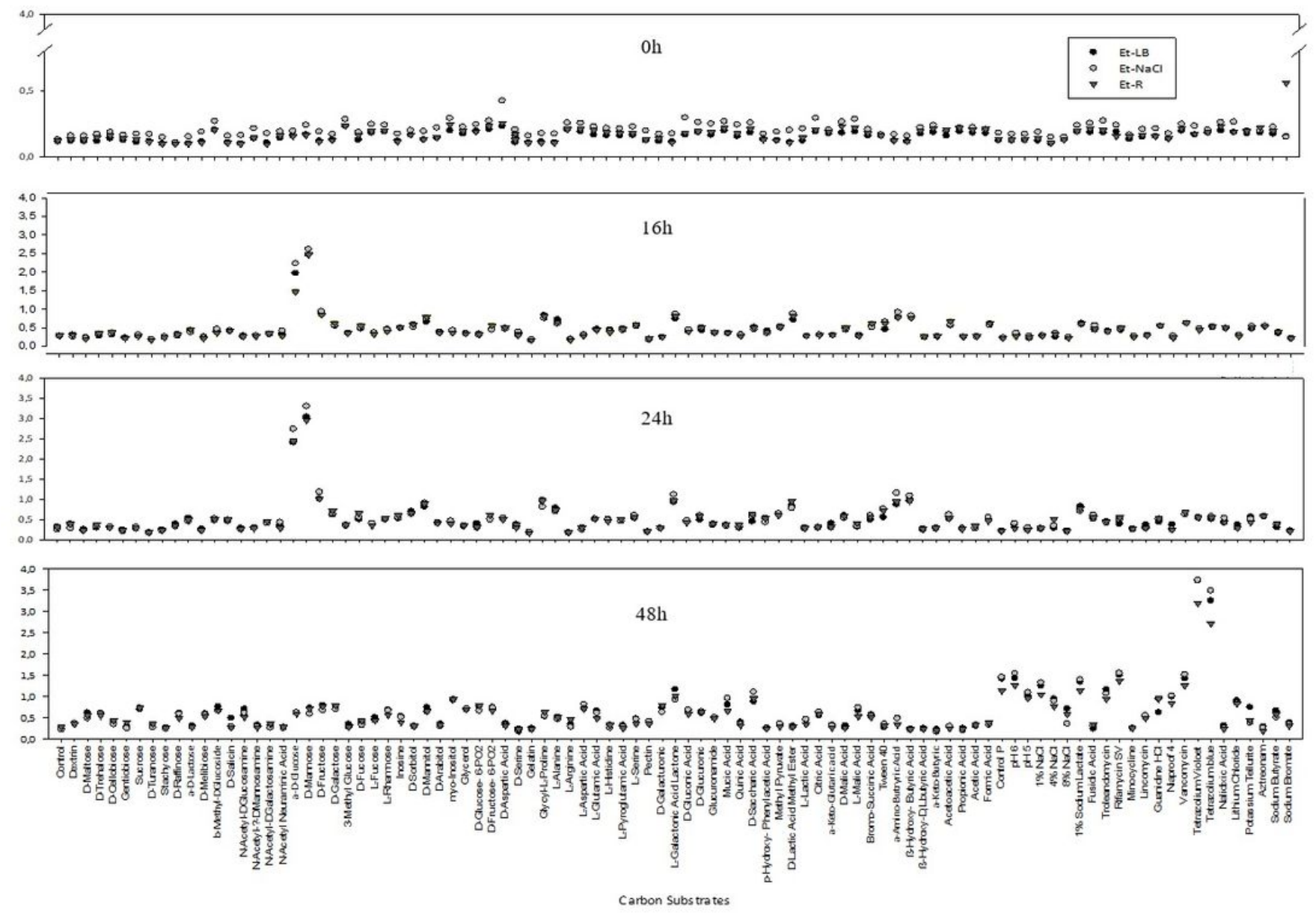

\section{Figure 2}

Average optical densities of Et-LB (black circle), Et-NaCl (white circle) and Et-R (triangle) at $0 \mathrm{~h}, 16 \mathrm{~h}, 24 \mathrm{~h}$ and $48 \mathrm{~h}$ at $28^{\circ} \mathrm{C}$ in the presence of 71 carbon substrates and 23 chemicals for sensitivity assay, from Biolog's GEN III plate (absorbance of 595nm) p $<0.05$ 


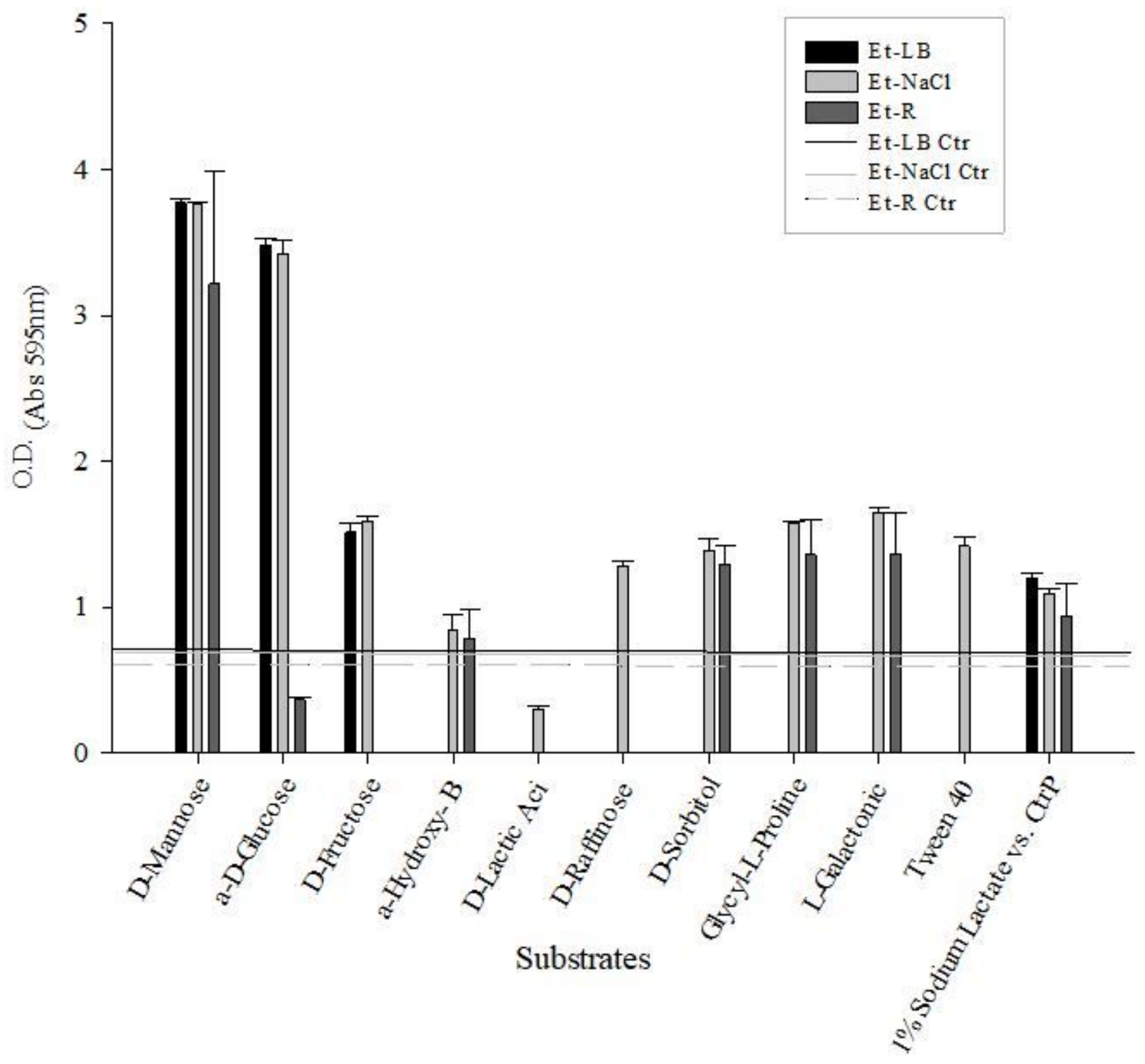

Figure 3

Average optical density of carbon substrates for which a significant difference in consumption relatively to each respective control at $0 \mathrm{~h}$ occurred in Erwinia toletana (Et-LB, Et-NaCl and Et-R), after $48 \mathrm{~h}$ of incubation at $28^{\circ} \mathrm{C}$. The respective control of Et-LB, Et-NaCl and Et-R was $0.69,0.68$ and $0.60(P<0.05)$. Error bars correspond to standard deviation 


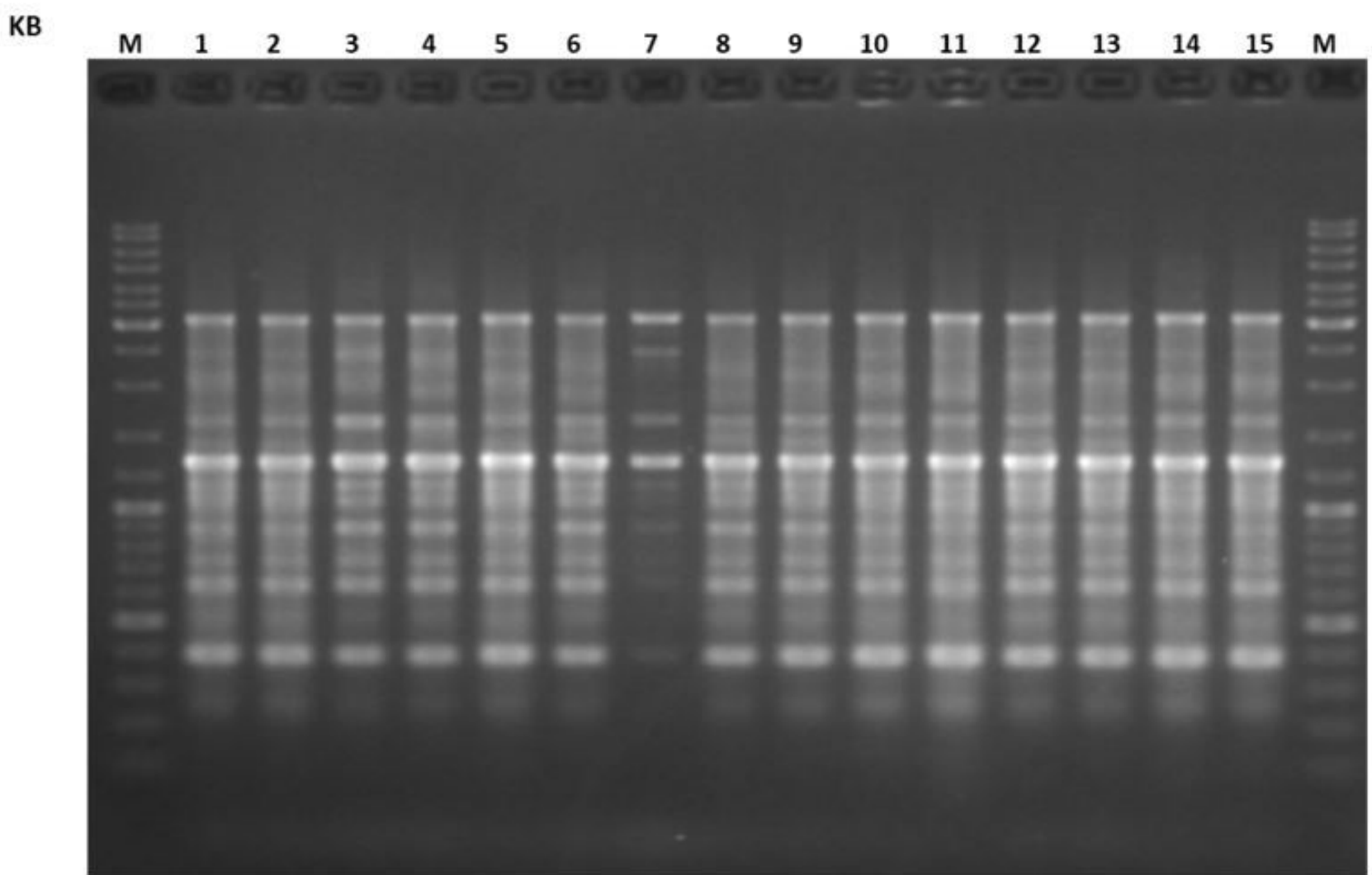

\section{Figure 4}

Gel Electrophoresis (1X TAE) of PCR products obtained by BOX-PCR of Erwinia toletana populations exposed to different treatments. Legend: M- DNA Marker (Gene Ruler 1kb Plus; Thermofisher), 1-5: Five replicates of Et-LB; 6-10: Five replicates of Et-NaCl and 11-15: Five replicates of Et-R 